Jurnal Penelitian Perawat Profesional

Volume 3 Nomor 1, Februari 2021

e-ISSN 2715-6885; p-ISSN 2714-9757

http://jurnal.globalhealthsciencegroup.com/index.php/JPPP

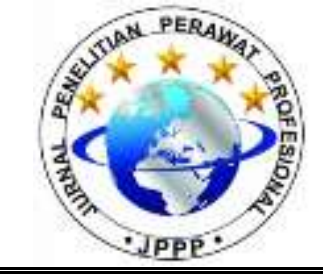

\title{
MANFAAT JAHE MERAH DALAM MENURUNKAN KADAR KOLESTEROL DARAH
}

\author{
Siti Noor Fadilah Bulfiah \\ Fakultas Kedokteran, Universitas Lampung, Jl. Prof. DR. Ir. Sumatri Brojonegoro No.1, Gedong Meneng, \\ Kec. Rajabasa, Kota Bandar Lampung, Lampung, Indonesia 35145 \\ sitinoorfadilahbulfiah@gmail.com (+6282278312762)
}

\begin{abstract}
ABSTRAK
Penyakit kardiovaskuler menyebabkan mordibitas dan mortalitas di seluruh dunia, sehingga hal ini menjadi perhatian utama bagi pemerintah dan Organisasi Kesehatan Dunia. Penyakit jantung koroner merupakan penyakit kardiovaskuler yang menyebabkan kematian terbesar, disebabkan penyempitan atau penyumbatan pada pembuluh darah koroner akibat dislipidemia. Berbagai penelitian telah dilakukan untuk mengatasi penyakit dislipidemia salah satunya adalah dengan pemberian jahe merah. Tujuan untuk menganalisis potensi jahe merah dalam menurunkan kolesterol darah. Literature review dilakukan dengan menggunakan sumber referensi dari kumpulan artikel yang dilakukan dengan literature searching pada Google Scholar dan NCBI dengan kata kunci dislipidemia, jahe merah, kolesterol, peyakit kardiovaskuler dalam rentang waktu 2001-2020 kemudian dianalisis dengan metode systematic literature review yang mencakup pengumpulan, evaluasi, dan pengembangan penelitian dengan fokus topik tertentu. Analisis berbagai artikel penelitian diketahui bahwa kandungan gingerol dalam jahe memiliki efek hipokolesterol, anti-aterogenik serta penekanan aktivitas enzim HMG-KoA reduktase sehingga dapat mengurangi biosintesis kolesterol total.
\end{abstract}

Kata kunci: dislipidemia; jahe merah; kolesterol; peyakit kardiovaskuler

\section{BENEFITS OF RED GINGER TO DECREASE BLOOD CHOLESTEROL LEVEL}

\begin{abstract}
Cardiovascular disease causes morbidity and mortality worldwide, so it is a major concern for governments and the World Health Organization. Coronary heart disease is a cardiovascular disease that causes the largest death, caused by narrowing or blockage of the coronary arteries due to dyslipidemia. Various studies have been conducted to overcome dyslipidemia, one of which is by giving red ginger. The aim was to analyze the potential of red ginger in lowering blood cholesterol. Literature review was carried out using reference sources from a collection of articles conducted with literature searching on Google Scholar and NCBI with the keywords dyslipidemia, red ginger, cholesterol, cardiovascular disease in the 2001-2020 period then analyzed using a systematic literature review method which includes collection, evaluation, and research development with a specific topic focus. Analysis of various research articles found that gingerol content in ginger has a hypocholesterolemic, anti-atherogenic effect and suppresses the activity of the HMG-CoA reductase enzyme so that it can reduce total cholesterol biosynthesis.
\end{abstract}

Keywords: cardiovascular disease; cholesterol; dyslipidemia; red ginger

\section{PENDAHULUAN}

Penyakit kardiovaskuler yang sering mengakibatkan kematian saat ini sudah banyak terjadi di negara berkembang seperti di Indonesia. Penyakit kardiovaskuler tidak hanya menyerang pada usia lanjut namun semakin banyak orang usia muda yang mengidapnya. Menurut badan kesehatan dunia (WHO) pada tahun 2008 , setidaknya 17,3 juta 
orang meninggal akibat penyakit kardiovaskuler yang mewakili 30\% dari seluruh kematian global akibat hiperkolesterol (WHO, 2017). Penyakit jantung koroner (PJK) merupakan penyakit kardiovaskuler yang menyebabkan kematian terbesar, disebabkan penyempitan atau penyumbatan pada pembuluh darah koroner akibat dislipidemia (Murray et al., 2003). Dislipidemia merupakan kelainan metabolisme lipid ditandai dengan peningkatan kadar kolesterol total, trigliserida, Low Density Lipoprotein (LDL) serta penurunan kadar High Density Lipoprotein (HDL), menyebabkan terjadi penurunan enzim antioksidan dan peningkatan peroksidasi lipid, berperan pada proses terjadinya aterosklerosis yang dapat berkembang menjadi penyakit stroke dan kematian (Kaviarasan dkk., 2005)

Kolesterol merupakan komponen utama pada plak aterogenik dan banyak studi telah mengaitkan penyakit jantung dan pembuluh darah dengan peningkatan kolesterol Dan merupakan alkohol steroid salah satu turunan lemak yang berada dalam darah dan sel tubuh (Sareen dkk., 2009). Kolesterol digunakan sebagai pembentuk dari dinding sel serta sebagai bahan pembentuk hormone (Chou, 2007). Kolesterol dalam darah digunakan sebagai zat prekursor pembentuk garam empedu di hati, dan stabilisasi membran sel, juga sebagai hormon steroid (Kee, 2007). Kadar kolesterol dikatakan normal jika berada dibawah $200 \mathrm{mg} / \mathrm{dl}$ dan dikatakan tinggi apabila berada pada jumlah $\geq 200 \mathrm{mg} / \mathrm{dl}$ (Kemenkes, 2014).

Lipoprotein plasma biasa dibagi atas empat berdasarkan sifat dan kepadatannya; kilomikron, Very Low Density Lipoprotein (VLDL), Low
Density Lipoprotein (LDL), High Density Lipoprotein (HDL) (Botham dan Mayes, 2009). Namun secara umum hanya dikenal LDL dan HDL saja. Pada keadaan normal, sekitar $70 \%$ kolesterol dalam plasma darah terkandung didalam LDL. Pembeda antara LDL dan HDL salah satunnya dari bagian proteinnya dimana LDL memiliki apolipoprotein B sedangkan HDL tidak. Apolipoprotein $B$ ini memungkinkan LDL berikatan dengan afinitas tinggi pada reseptor LDL di permukaan sel terutama pada pembuluh darah. Selain itu, LDL mengandung $20 \%$ protein sedangkan HDL mengandung lebih banyak protein yakni sekitar 40\% (Boyer, 2006).

Adanya peningkatan kadar HDL dapat mencegah gangguan metabolisme hingga kegemukan. HDL mengandung apolipoprotein A-1 (ApoA-1) yang menjadi konstituen utama dari struktural protein pada HDL dan berperan penting dalam pembentukan HDL itu sendiri. Selain itu, ATP pengikat molekul pengangkut A-1 (ABCA1) dan lesitin: Kolesterol asiltransferase (LCAT) berkonstribusi dalam sintesis HDL (Murray et al., 2003).

Peningkatan kadar kolesterol dalam darah akan meningkatkan kadar LDL karena kandungan kolesterol yang dibawa oleh LDL lebih banyak dibandingkan HDL (Murray et al., 2003). Adanya peningkatan kadar LDL akan menyebabkan penumpukan plak di pembuluh darah terutama arteri koroner dan akan menimbulkan berbagai penyakit. Diantara penyakit yang timbul ialah hiperkolesteromia, arteriosclerosis, hingga penyakit jantung koroner yang dapat menyebabkan kematian (Ayu et al., 2018)

Menurut penelitian kedokteran molekuler terbaru, didapatkan bahwa 
jenis dislipidemia yang paling berbahaya adalah dislipidemia aterogenik. Deposit kolesterol LDL dislipidemia aterogenik pada dinding pembuluh darah arteri menjadi salah satu penyebab terjadinya disfungsi endotel sebagai proses awal terbentuknya plak aterosklerosis. Lipid, khususnya low density lipoprotein (LDL) saat ini mulai banyak diteliti sebagai nilai prediksi pada PJK, mengingat perannya dalam proses aterogenesis (Sany, 2009).

Modifikasi diet dan pengaturan makan merupakan upaya preventif dari penyakit jantung dan pembuluh darah. Pengaturan makan dapat dilakukan dengan membatasi asupan makanan yang mengandung kolesterol dan lemak serta konsumsi makanan yang memiliki manfaat dalam menurunkan kolesterol total. Jahe merah (Zingiber officinale var. Rubrum) merupakan salah satu jenis jahe yang dapat menurunkan kolesterol darah. Jahe termasuk dalam rempah-rempah yang telah banyak dimanfaatkan untuk obat tradisional dan bahan makanan fungsional yang mudah tumbuh di Indonesia.

Senyawa yang terdapat pada jahe adalah senyawa volatile dan non volatile. Senyawa volatile terdiri dari berbagai senyawa terpenoid, sedangkan senyawa non volatile terdiri dari gingerol, shogaol, paradol, zingerone dan turunan mereka serta senyawa-senyawa flavonoid dan polifenol yang mempunyai efek antioksidan dapat mencegah adanya radikal bebas dalam tubuh (Stailova, 2007).

\section{METODE}

Metode yang digunakan dalam penulisan artikel ini adalah literature review. Penulisan artikel ini merupakan penggabungan artikel dengan rentang tahun 2001-2020. Referensi yang didapat dilakukan dengan literature searching dari database Google Scholar dan NCBI dengan kata kunci dislipidemia, jahe merah, kolesterol, peyakit kardiovaskuler dalam rentang waktu 2001-2020. Sumber bacaan yang telah dipilih ini kemudian dianalisis dengan metode systemathic literature review yang meliputi pengumpulan data, evaluasi, dan pengembangan penelitian dengan fokus tertentu.

\section{HASIL}

Pemberian ekstrak etanol dari jahe pada hewan coba dapat menurunkan kolesterol total secara signifikan, hal ini dikarenakan kandungan yang terdapat pada jahe dapat menurunkan aktifitas HMG-KoA dan atau meningkatkan reseptor LDL. Regulasi HMG-KoA reduktase dan reseptor LDL oleh ekstrak etanol jahe memberikan efek pada sirkulasi kolesterol total, trigliserid dan kolesterol LDL dengan mengurangi biosintesis kolesterol dan meningkatkan serapan kolesterol LDL oleh hati.

Pemberian minuman jahe merah sebanyak 3,2 ml/kg BB per hari selama 21 hari memberikan pengaruh penurunan rerata kadar kolesterol total sebesar 8,64\%. Hasil statistik menunjukkan bahwa terdapat perbedaan yang signifikan antara rerata kadar kolesterol total sebelum dan setelah intervensi pada kelompok perlakuan. Rerata kadar kolesterol pada kelompok kontrol mengalami kenaikan sebesar $5,34 \%$.Penurunan yang terjadi pada kelompok perlakuan sejalan dengan penelitian sebelumnya yang pernah dilakukan pada tikus yang diinduksi aloksan yang diberikan jus jahe $\begin{array}{lllll}\text { sebanyak } 4 & \mathrm{ml} / \mathrm{kg} & \mathrm{BB} & \text { dapat }\end{array}$ menurunkan kolesterol total pada 
kelompok perlakuan secara signifikan (Resti \& Hesti, 2014).

Penurunan kadar kolesterol total pada kelompok perlakuan juga sejalan dengan penelitian pada tikus yang diberikan $250 \mathrm{mg} / \mathrm{hari}$ ekstrak jahe selama 10 minggu dapat menurunkan kolesterol total sebesar $29 \%$ dan terdapat penurunan tingkat biosintesis kolesterol sebesar 76\%. Pengurangan biosintesis kolesterol berkaitan dengan peningkatan aktivitas reseptor LDL yang dapat meningkatkan pembuangan kadar LDL dari plasma sehingga mengurangi konsentrasi kolesterol plasma. Penurunan yang terjadi pada kelompok perlakuan sejalan dengan penelitian sebelumnya yang pernah dilakukan pada tikus yang diinduksi aloksan yang diberikan jus jahe sebanyak $4 \mathrm{ml} / \mathrm{kg} \quad \mathrm{BB}$ dapat menurunkan kolesterol total pada kelompok perlakuan secara signifikan (Resti \& Hesti, 2014). Hal ini sejalan dengan penelitian yang dilakukan pada tahun 2010 terhadap tikus diberikan makan ekstrak jahe secara signifikan mengalami peningkatan kadar HDL di dalam darah (Elrokh et al., 2010).

\section{PEMBAHASAN}

Kolesterol merupakan komponen utama pada plak aterogenik dan banyak studi telah mengaitkan penyakit jantung dan pembuluh darah dengan peningkatan kolesterol Dan merupakan alkohol steroid salah satu turunan lemak yang berada dalam darah dan sel tubuh (Sareen dkk., 2009). Adanya peningkatan kadar LDL akan menyebabkan penumpukan plak di pembuluh darah terutama arteri koroner dan akan menimbulkan berbagai penyakit. Diantara penyakit yang timbul ialah hiperkolesteromia, arteriosclerosis, hingga penyakit jantung koroner yang dapat menyebabkan kematian (Ayu et al., 2018).

Dislipidemia merupakan kelainan metabolisme lipid ditandai dengan peningkatan kadar kolesterol total, trigliserida, Low Density Lipoprotein (LDL) serta penurunan kadar High Density Lipoprotein (HDL), menyebabkan terjadi penurunan enzim antioksidan dan peningkatan peroksidasi lipid (Kaviarasan dkk., 2005). Penurunan kadar kolesterol total dipengaruhi oleh kandungan dalam jahe yaitu senyawa flavonoid dan polifenol yang dapat mencegah adanya radikal bebas dalam tubuh, memiliki efek hipokolesterol, antiaterogenik, penekanan aktivitas enzim HMG-KoA reduktase yang berperan dalam sintesis kolesterol.

Modifikasi diet dan pengaturan makan merupakan upaya preventif dari penyakit jantung dan pembuluh darah. Pengaturan makan dapat dilakukan dengan membatasi asupan makanan yang mengandung kolesterol dan lemak serta konsumsi makanan yang memiliki manfaat dalam menurunkan kolesterol total. Jahe merah (Zingiber officinale var. Rubrum) merupakan salah satu jenis jahe yang dapat menurunkan kolesterol darah.

Senyawa yang terdapat pada jahe adalah senyawa volatile dan non volatile. Senyawa volatile terdiri dari berbagai senyawa terpenoid, sedangkan senyawa non volatile terdiri dari gingerol, shogaol, paradol, zingerone dan turunan mereka serta senyawa-senyawa flavonoid dan polifenol yang mempunyai efek antioksidan dapat mencegah adanya radikal bebas dalam tubuh (Stailova, 2007).

Senyawa polifenol dapat mencegah terjadinya oksidasi LDL secara in vitro 
dan memiliki aktivitas hipolipidemik secara in vivo sehingga dapat mencegah terjadinya aterosklerosis. Aktivitas hipolipidemik pada polifenol mungkin disebabkan karena penghambatan penyerapan kolesterol di usus atau produksi oleh hati atau peningkatan ekskresi kolesterol melalui asam empedu dan ekskresi kolesterol melalui feses. Dilaporkan bahwa senyawa 6gingerol dari jahe meningkatkan sintesis HDL dan menambah aktivitas LCAT (Lesitin Kolesterol Asiltrasnferase) (Saravanan et al., 2014). LCAT ialah enzim yang berperan penting dalam proses transportasi kolesterol balik. Enzim ini bertanggung jawab dalam pembentukan

HDL dan pemodelan ulang partikel lipoprotein HDL (Brahma, 2015).

Fungsi utama dari HDL yakni untuk menghilangkan kolesterol dari jaringan poliferal dan mengangkutnya menuju hati untuk ekskresi empedu dalam proses transportasi kolesterol balik. Selanjutnya kolesterol diangkut ke apolipoprotein ApoA-1 yang kekurangan lipid. Hal tersebut diikuti dengan esterifikasi dari kolesterol bebas pada permukaan dari HDL yang baru oleh LCAT, lalu membuat sebuah gradien kolesterol bebas antara jaringan peripheral dan hati (Zannis,2004).

Gingerol yang merupakan salah satu senyawa bioaktif pada jahe juga dapat menghambat biosintesis kolesterol dengan cara menghambat akses dari substrat menuju sisi aktif dari enzim HMG-CoA reduktase. Tingkat konsentrasi HMG-CoA reduktase pada percobaan tikus gemuk secara signifikan diturunkan oleh gingerol yang menunjukkan bahwa adanya penurunan sintesis kolesterol (Brahma, 2016).

\section{SIMPULAN}

Gingerol pada jahe dapat signifikan menurunkan kadar kolesterol tinggi dalam darah dengan meningkatkan kadar LCAT sehingga meningkatkan kadar HDL dalam darah serta mengaktifkan lipoprotein lipase yang membantu LDL bergerak membawa kolesterol dalam darah. Gingerol juga dapat menghambat biosintesis kolesterol dengan cara menghambat akses dari substrat menuju sisi aktif dari enzim HMG-CoA reduktase.

\section{DAFTAR PUSTAKA}

Arablou, T., Aryaeian, N. (2017). The effect of ginger (Zingiber Officinale) as an ancient medicinal plant on improving blood lipids. J Herb Med :13-7. doi: 10.1515/jcim-2014-0021.

Ayu, A. M, Mutalazimah, M, dan Herawati I. (2018). Hubungan Frekuensi Senam Aerobik dan Asupan Kolesterol terhadap Kadar Kolesterol Darah Wanita Usia Subur di Pusat Kebugaran Syariah Agung Fitnes Makam haji. Jurnal Kesehatan. 10(2). 74-82 doi:https://doi.org/10.23917/jk.v1 $0 \mathrm{i} 2.5536$

Brahma, N. P. (2015). Ameliorative potential of gingerol: Promising modulation of inflammatory factors and lipid marker enzymes expressions in HFD induced obesity in rats. Mol. Cell. Endocrinol. 419:139-47. doi: 10.1016/j.mce.2015.10.007

Botham, K. M dan Mayes P.A. (2009). Sintesis, Transpor, \& Ekskresi Kolesterol," in Biokimia Harper.

Boyer, S. H. (2006). The Principles of Human Biochemical Genetics. Harry Harris. North-Holland, 
Amsterdam, and Elsevier, New York, 1970. xiv, 330 pp., illus. Cloth, \$15; paper, $\$ 6.95$. Frontiers of Biology, vol. 19," Science (80).

Chou D, (2017). Henry's Clinical Diagnosis And Management By Laboratory Methods. JAMA The Journal of the American Medical Association. 297(16):1829-1829. doi: 10.1001/jama.297.16.1829

Dugasani, S., Pichika, M. R., Nadarajah, V. D, Balijepalli, M. K, Tandra, S., \& Korlakunta J. N. (2010). Comparative antioxidant and anti-inflammatory effects of gingerol. Third Edition. J. Ethnopharmacol. 127(2):515-20. doi:10.1016/j.jep.2009.10.004

Elrokh, E. S., Yassin, M. A., ElShenawy, dan Ibrahim, B. M. M. (2010).Antihypercholesterolaemic effect of ginger rhizome (Zingiber officinale) in rats. Inflammopharmacology. (1):263-274

Hesti M., Resti P. (2014). Pengaruh Pemberian Jahe Merah (Zingiber Officinale Var Rubrum) Terhadap Kadar Kolesterol Total Wanita Dislipidemia. Journal of Nutrition College, 3(4):798-806.

Kaviarasan, K., Arjunan, M. M., \& Pugalendi, K. V. (2005). Lipid profile, oxidant-antioxidant status and glycoprotein components in hyperlipidemia patients with/without diabetes. Clin. Chim. Acta. 362(1-2):49-56. doi: 10.1016/j.cccn.2005.05.010

Kee L.J. (2014). Pedoman pemeriksaan laboratorium dan diagnostik. Jakarta EGC.
Kementerian Kesehatan Republik Indonesia. The Indonesian Health Department. (2014). Pedoman Gizi Seimbang.

McLaughlin, S. P. Ginger: The Genus Zingiber. (2005). Medicinal and Aromatic Plants-Industrial Profiles, 41(22):2145. doi: 10.3390/molecules22122145

Murray, R. K., Granner, D. K., Mayes, P. A., Rodwell, V. W. (2003). Biokimia Harper, Edisi XXV. Penerjemah Hartono Andry. Jakarta: EGC.

Sareen, S. G., Jack, L. S., James, L. G. (2009). Advanced Nutrition, Metabolism.Canada:Wadsworth Cengage Learning.

Saravanan, G., Ponmurugan P., Deepa M. A., \& Senthilkumar B. (2014). Anti-obesity action of gingerol: Effect on lipid profile, insulin, leptin, amylase and lipase in male obese rats induced by a high-fat diet. J. Sci. Food Agric.

94(14):29727.doi:10.1002/jsfa.6642

Sany RS. (2009). Dislipidemia Sebagai Faktor Risiko Utama Penyakit Jantung Koroner. Cermin Dunia Kedokteran, 36(3):181- 184.

Stailova, I., Krastanov, A., Stoyanova, A. (2007). Antioxsidant Activity of Ginger Extract (zingiber officinale).Food Chemistry. 102(3):764-770. doi: 10.1016/j.foodchem.2006.06.023

Tzeng T. F, Liou S.S, Chang C.J , dan Liu I.M. (2015). 6-Gingerol Protects Against Nutritional Steatohepatitis By Regulating Key Genes Related To Inflammation And Lipid Metabolism. Phytother. 
Res. 7(2): 999-1020. doi:

$10.3390 /$ nu7020999

World Health Organization. (2017)

Media Centre: Cardiovascular disease.

Zannis, V. I. (2004). Probing the pathways of chylomicron and HDL metabolism using adenovirus-mediated gene transfer, Current Opinion in Lipidology. 15(2):151-66. doi: 10.1097/00041433-20040400000008 . 
Jurnal Penelitian Perawat Profesional, Volume 3 No 1 Hal 79 - 86, Februari 2021 Global Health Science Group 